\title{
Rescue of Lesioned Septal Cholinergic Neurons by Nerve Growth Factor: Specificity and Requirement for Chronic Treatment
}

\author{
Claudia N. Montero and Franz Hefti \\ Department of Neurology, University of Miami Medical School, Miami, Florida 33101
}

We earlier reported that chronic intraventricular injections of NGF into adult rats with partial transection of the fimbria prevent the lesion-induced disappearance of cholinergic neurons in the medial septal nucleus and the diagonal band of Broca (Hefti, 1986). The present study assessed the specificity and treatment requirements of this effect of NGF. Immunohistochemical visualization of NGF receptors (NGF-R) revealed that these molecules are selectively located in forebrain cholinergic neurons of unlesioned brains. Fimbrial transection resulted in transient accumulation of NGF- $R$ in proximal stumps of lesioned axons but failed to induce the expression of NGF-R by other cells in the septal area or near the lesion. Two to three weeks after lesioning, the number of septal neurons expressing NGF-R was reduced by approximately $50 \%$ in parallel with the reduction of the number of neurons expressing cholinergic marker enzymes. Repeated intraventricular NGF injections during 4 weeks prevented the disappearance of these cells. Fimbrial transections also reduced the number of septal GABAergic neurons visualized by glutamate decarboxylase immunohistochemistry. The loss of GABAergic neurons was not prevented by NGF. These findings suggest that NGF prevents the lesioninduced degeneration of cholinergic neurons by directly acting on NGF-R expressed by cholinergic cells and that NGF does not affect any neuron with an axonal lesion. Delayed start of the NGF treatment failed to prevent the disappearance of lesioned cholinergic neurons, providing evidence that NGF treatment indeed promotes the survival of these cells rather than simply upregulating the expression of transmitter-specific enzymes. A single injection of NGF at the time of the lesion was not sufficient to prevent the lesioninduced degeneration of cholinergic neurons. Furthermore, termination of chronic NGF treatment after 4 weeks was followed by loss of septal cholinergic neurons after an additional 4 weeks. These findings suggest that the continuous presence of NGF during more than 4 weeks is required to prevent the degeneration of cholinergic cells. The data are discussed in the context of a possible physiological role of NGF in the function of adult forebrain cholinergic neurons.

\footnotetext{
Received Aug. 6, 1987; revised Oct. 25, 1987; accepted Dec. 3, 1987.

The study was supported by NIH Grant NS22933 and grants from the Alzheimer's Disease and Related Disorders Association, Chicago (P-85-004), and the National Parkinson Foundation, Miami.

Correspondence should be addressed to Dr. F. Hefti, Department of Neurology, University of Miami, P.O. Box 016960, Miami, FL 33101.

Copyright (C) 1988 Society for Neuroscience $0270-6474 / 88 / 082986-14 \$ 02.00 / 0$
}

Cholinergic neurons in medial septum, the nucleus of the diagonal band of Broca, and the nucleus basalis form a continuum of cells that provides a widespread and topographically organized innervation for cortical and limbic structures. This group of neurons is referred to as the "magnocellular basal nucleus" and the projection as "ascending cholinergic projection of the basal forebrain" (Mesulam and vanHoesen, 1976; Fibiger, 1982; Eckenstein and Sofroniew, 1983; McKinney et al., 1983; Mesulam et al., 1983a, b; Saper and Chelimsky, 1984; Wainer et al., 1984; Butcher and Woolf, 1986). In recent years evidence has accumulated suggesting that NGF is involved in the function of this group of cholinergic neurons. Similar to the well-established role in the development of peripheral sympathetic and sensory neurons, NGF affects development of cholinergic neurons in the forebrain. Addition of NGF to cultures containing embryonic cholinergic neurons stimulates the expression of choline acetyltransferase (ChAT) activity (I Ionegger and Lenoir, 1982; Hefti et al., 1985; Hatanaka and Tsukui, 1986; Honegger et al., 1986; Martinez et al., 1987). In cultures of dissociated septal neurons grown at low density, NGF stimulates the growth of cholinergic fibers (Hartikka and Hefti, 1988). NGF promotes the growth of cholinergic axons from cultured slices of septal tissue into cocultured slices of hippocampal tissue (Gähwiler et al., 1987). Furthermore, injections of NGF into the brain of newborn rats elevate ChAT activity in the target areas of the forebrain cholinergic neurons (Gnahn et al., 1983; Mobley et al., 1985, 1986). Levels of NGF and its mRNA (mRNANGF) develop parallel to the growth of cholinergic axons of the rat basal forebrain (Large et al., 1986; Whittemore et al., 1986; Auburger et al., 1987). Lesions of the septohippocampal pathway in neonatal rats result in increases of both $\mathrm{mRNA}^{\mathrm{NGi}}$ and NGF in the hippocampus (Whittemore et al., 1987).

In adult rats, levels of NGF mRNA ${ }^{\mathrm{NGF}}$ corrclate with the anatomical distribution of basal forebrain cholinergic neurons (Crutcher and Collins, 1982; Korsching et al., 1985; Goedert et al., 1986; Shelton and Reichardt, 1986; Whittemore et al., 1986). NGF receptors (NGF-R) were demonstrated in the adult brain by crosslinking iodinated NGF (Taniuchi et al., 1986b) and were visualized on forebrain cholinergic neurons in rat and human brains using autoradiographic and immunohistochemical techniques (Hefti et al., 1986; Richardson et al., 1986; Raivich and Kreutzberg, 1987; Springer et al., 1987). These receptors mediate internalization and retrograde transport of NGF by cholinergic neurons (Schwab et al., 1979; Seiler and Schwab, 1984). The receptors themselves are transported anterogradely and retrogradely within forebrain cholinergic axons (Taniuchi et al., 1986b; Johnson et al., 1987). NGF synthesized by cholinergic target areas was implied in the sprouting of sympathetic fibers 
into these arcas occurring after lesions of cholinergic pathways (Crutcher, 1987).

Despite the well-established presence of NGF and NGF-R in the adult brain, it is not clear whether NGF is required for the maintenance and function of developed forebrain cholinergic neurons. However, it has been shown that exogenously administered NGF is able to affect forebrain cholinergic neurons trophically after axonal injury. During the past years, we have studied the effects of intraventricular administration of NGF to adult rats with partial transections of the fimbria, which result in a partial lesion of the septohippocampal cholinergic pathway. This pathway was chosen because it represents the best characterized part of the ascending cholinergic projections from the basal forebrain and because the axons are easily accessible for lesioning in the fimbria. Partial, rather than complete, lesions of this pathway were chosen so as to be able to study the effects of NGF on neuronal cell bodies in the septum as well as the effects on surviving axons in the hippocampus. Furthermore, partial lesions also leave a natural bridge between septum and hippocampus through which severed axons might regenerate. Initial observations revealed that intraventricular injections of NGF to such animals elevate both hippocampal and septal ChA I activity (Hefti et al., 1984; Will and Hefti, 1985). Later, we found that the partial fimbrial transections resulted in a retrograde degeneration of part of the group of septal cholinergic neurons projecting to the hippocampus and that chronic intraventricular injections of NGF prevented this lesion-induced degeneration (Hefti, 1986). Similar findings were obtained in animals with complete transection of the fimbria (Kromer, 1986; Williams et al., 1986).

Since our initial reports, antibodies against NGF-R have become available (Chandler et al., 1984), permitting direct visualization of NGF-responsive cells by immunohistochemical procedures. These antibodies were used to establish that NGF directly affects cholinergic neurons. The initial studies, in which cholinergic neurons were identified with acetylcholinesterase (AChE) histochemistry, did not exclude the possibility that NGF treatment did not improve survival of the cells, but only upregulated the expression of AChE. This question was addressed in the present study by giving NGF after an interval of time sufficient to result in the disappearance of both cholinergic marker enzymes, ChAT and AChE, and by testing whether the delayed treatment induced the reappearance of the cells. We also assessed whether chronic application of NGF was required for the rescue of cholinergic cells or whether initial treatment of NGF after lesioning was just as effective. Furthermore, we analyzed whether NGF treatment resulted in permanent survival of cholinergic neurons; additionally, we tested whether NGF affects GABAergic septohippocampal neurons.

\section{Materials and Methods}

\section{Fimbrial transections and NGF treatment}

A total of 91 adult female Wistar rats $(200 \mathrm{gm})$ received a unilateral partial transection of the septohippocampal pathway as described in detail elsewhere (Hefti et al., 1984; Hefti, 1986; Fig. 1). A cannula was implanted in the lateral ventricle ipsilateral to the lesion and fixed permanently. The animals were injected through the cannula twice a week with $5 \mu \mathrm{g}$ of $2.5 \mathrm{~S}$ NGF (purified from mouse salivary glands according to Suda et al., 1978) or an equal amount of cytochrome $c$ (which has similar biochemical properties as NGF but no activity on NGF receptors and served as a control protein). NGF and cytochrome c were injected in a volume of $5 \mu \mathrm{l}$ of PBS containing $15 \mathrm{mg} / \mathrm{ml}$ of gentamycin. The first injection of NGF or cytochrome $\mathrm{c}$ was normally given on the day of lesioning.
At various times after the lesion, NGF-treated and control animals were taken for immunohistochemical analysis. They were perfused intracardially with $200 \mathrm{ml}$ PBS containing 10 units/ml heparin, followed by $400 \mathrm{ml}$ of $4 \%$ paraformaldehyde and $5 \%$ sucrose in PBS. The brains were removed and immersed for $24 \mathrm{hr}$ in PBS containing $10 \%$ sucrose, followed by $24 \mathrm{hr}$ in PBS with 20\% sucrose and $24 \mathrm{hr}$ in PBS with $30 \%$ sucrose. Brains were then frozen in liquid nitrogen and stored at $-70^{\circ} \mathrm{C}$ for up to a month. For sectioning, they were embedded in Tissue-Tek (Miles), and 30- or 45- $\mu$ m-thick sections of the entire medial septal nucleus and the diagonal band of Broca were cut on a freezing microtome; the 30- and 45- $\mu$ m-thick sections were used for AChE histochemistry and immunohistochemical procedures, respectively. Sections were transferred into PBS and kept in this solution for 2-6 hr before starting the immunohistochemical staining.

\section{Histochemistry}

$N G F-R$ immunohistochemistry. Floating sections were incubated overnight at $4^{\circ} \mathrm{C}$ with a mouse monoclonal antibody against NGF-R (192IgG; Chandler et al., 1985; $2.5 \mu \mathrm{g} / \mathrm{ml}$ in PBS containing horse serum, $1: 100,5 \%$ bovine serum albumin, $5 \%$ sucrose, and $0.1 \%$ Triton $x-100$ ). After washing with PBS for $2 \mathrm{hr}$, they were incubated with a rat-adsorbed biotinylated horse anti-mouse antibody (Vectastain, 1:200) for $30 \mathrm{~min}$. Endogenous peroxidase was then destroyed by incubating sections in $0.3 \% \mathrm{H}_{2} \mathrm{O}_{2}$ in PBS for 15 min. Sections were then washed in PBS and incubated in an avidin-biotin conjugate of peroxidase (Vectastain). After washing with PBS, the peroxidase was visualized by incubation for 3 $\mathrm{min}$ in a solution of diaminobenzidine hydrochloride (1 $\mathrm{mg} / \mathrm{ml}$ in PBS) containing $0.03 \% \mathrm{H}_{2} \mathrm{O}_{2}$ and $25 \mathrm{mg} / \mathrm{ml}$ of nickel ammonium sulfate as an intensifier. Vectastain Kits (Vector) were used for immunohistochemical stainings, and procedures used largely followed the instructions of the manufacturer. After staining, sections were transferred to slides, dehydrated, and mounted. In control sections the monoclonal antibody against NGF-R was replaced by nonspecific mouse IgGs.

ChAT immunohistochemistry. Sections taken for ChAT immunohistochemistry were incubated with a rat anti-ChAT monoclonal antibody (Eckenstein and Thoenen, 1982), diluted 1:4. The staining procedure used was the same as that for NGF-R using a biotinylated anti-rat antibody (Vectastain). The biotinylated antibody was preadsorbed with rat brain acetone powder. The antibody solution, $1 \mathrm{ml}$, was incubated with $10 \mathrm{mg}$ of brain powder at $4^{\circ} \mathrm{C}$ for $45 \mathrm{~min}$. Antibodies were then separated from the acetone powder by centrifugation $(3000 \times g$ for 60 min) and filtration through a small Millipore filter $(0.22 \mu \mathrm{m}$ pore size).

$A C h E$ histochemistry. Cholinergic cell bodies were visualized using AChE histochemistry after pretreatment with diisopropylfluorophosphate (DFP) according to Butcher et al. (1975), as described in detail in Hefti (1986).

Glutamic acid decarboxylase (GAD) immunohistochemistry. Animals were perfused intracardially with $200 \mathrm{ml}$ PBS containing 10 units $/ \mathrm{ml}$ heparin followed by $400 \mathrm{ml}$ of $4 \%$ formaldehyde, $0.5 \%$ zinc dichromate, and $0.45 \%$ sodium chloride, $\mathrm{pH} 4.0$ (Mugnaini and Oertel, 1985). The brains were removed and treated as described above. Floating sections were incubated overnight with a sheep monoclonal antibody against GAD (S3; Oertel et al., 1981), diluted 1:2000, and were processed in the same way as for NGF-R immunohistochemistry using a biotinylated anti-sheep antibody.

Cresyl violet staining. Nissl-stained (Clark, 1981) sections of the lesion area were taken to verify the lesion in each animal.

\section{Cell counting}

Frontal sections were cut between levels A6700 and A9000 (Koenig and Klippel, 1963), corresponding to the anteriormost part of the medial septal nucleus and the medial portion of the anterior commissure, respectively (see Fig. 2 in Hefti, 1986). The sectioned part of the brain contained the entire medial scptal nucleus and the diagonal band of Broca, i.e., the areas containing the cholinergic cell bodies projecting to the hippocampus (McKinney et al., 1983). Cholinergic neurons were ascribed to one of the following two groups; first, to medial septal nucleus and the vertical limb of the diagonal band of Broca (i.e., areas containing cholinergic neurons projecting to the hippocampus); second, to the horizontal limb of the diagonal band of Broca and substantia innominata (i.e., areas containing cholinergic neurons not projecting to the hippocampus). Cholinergic neurons were counted using a Leitz Dialux 22 microscope. For quantification of AChE-positive neurons, every sixth section was taken for counting and the total number of cells in the septal 
Figure 1. Transection of the fimbria formed in the present study. At anteroposterior level A6100 (Koenig and Klippel, 1963), a knife (8 mm long, 0.7 $\mathrm{mm}$ wide) was inserted into the brain at a position $1.2 \mathrm{~mm}$ lateral to the midline. The knife was then moved laterally and retrieved at the final lateral position. Because of the elasticity of the fimbria, and to ensure its transection, it was necessary to move the knife further laterally than the fimbria's normal position. Immediately after lesioning, a cannula was inserted at level A6400 into the lateral ventricle of the lesioned side and permanently fixed with dental cement. For intraventricular injections, a hypodermic needle attached to a Hamilton syringe was inserted through the cannula into the ventricle. $C F V$, ventral commissure of fornix; $C I$, internal cap$G P$, globus pallidus. and implantation of a cannula as persule; $C P$, caudate putamen; $F$, fimbria;

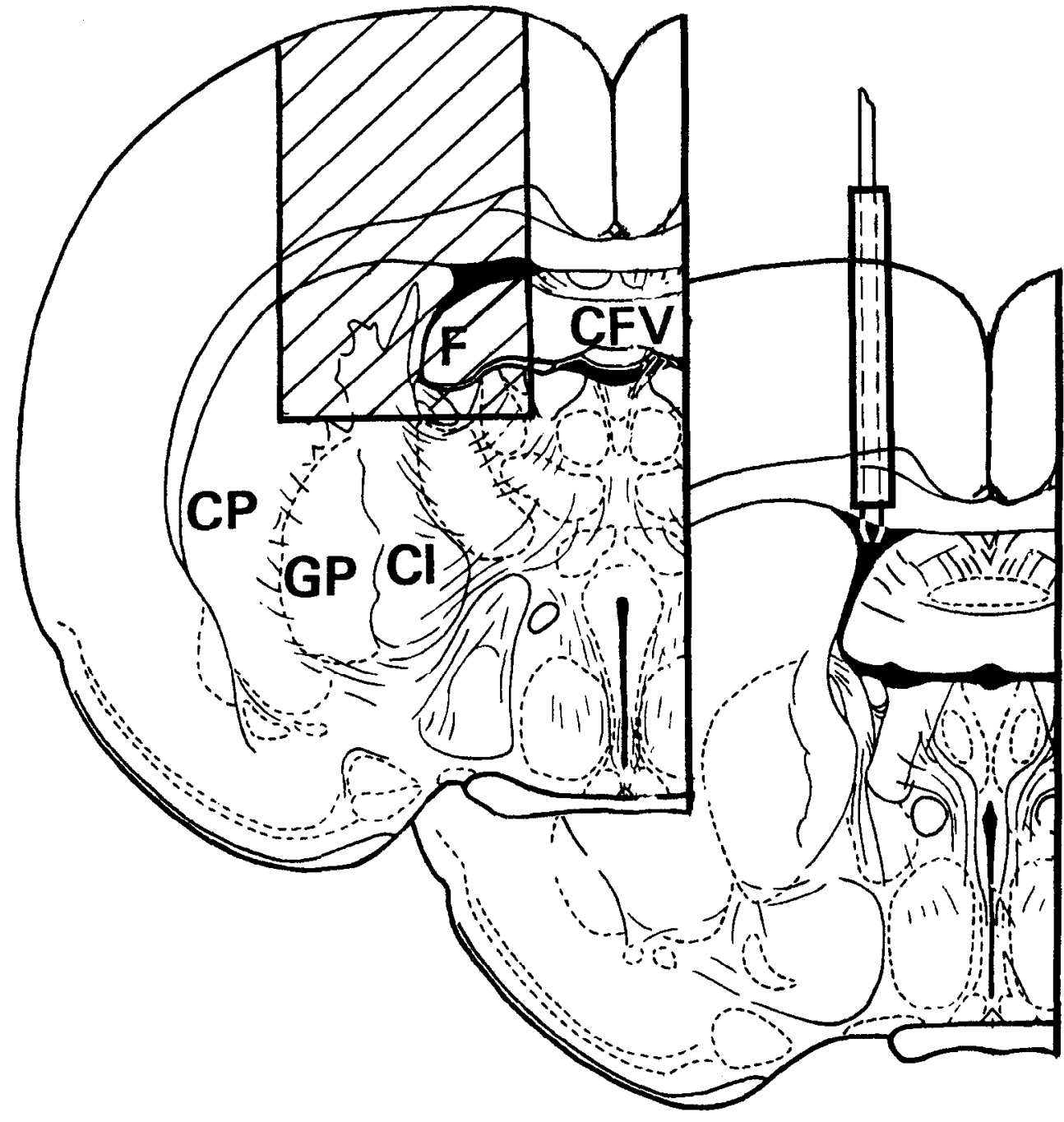

area was calculated by accounting for the omitted sections. For ChAT and NGF-R immunohistochemistry, the number of stained neurons counted on the lesioned side was expressed as the percentage of the number on the control side. Means of these percentages were then calculated for each animal. Analysis of percentage loss was chosen, because some sections were lost in the immunohistochemical procedures, which required handling of floating sections. The RS/ 1 data analysis system (BBN Software Products, Cambridge MA) was used for statistical analysis of the data.

\section{Results}

\section{Effect of fimbrial transections and chronic NGF treatment}

As earlier shown with Nissl staining and AChE histochemistry (Hefti, 1986), partial transection of the fimbria resulted in a loss of cholinergic neurons in the septal area. The number of ChATpositive cells in the medial septal nucleus and the vertical limb of the diagonal band of Broca declined gradually during the first $10 \mathrm{~d}$ after lesioning and remained at a constant level thereafter (Fig. 2). The lesions reduced the number of ChAT-positive cells on the lesioned side to an average of $38 \%$ of control values counted on contralateral sides (Table 1).

The number and morphology of neurons stained by NGF-R immunohistochemistry in the septal area were identical to those of ChAT-positive cells, indicating, in agreement with results obtained in other studies (Hefti et al., 1986; Springer et al., 1987 ) that, in the adult basal forebrain, NGF-R are selectively located on cholinergic neurons. Between 2 and $3 \mathrm{~d}$ after a unilateral fimbrial transection, there was a slight increase in the staining intensity of NGF-R-positive cells on the lesioned side. Thereafter, staining intensity and number of NGF-R-positive cells declined gradually and reached a plateau after approximately $10 \mathrm{~d}$ after lesioning. The lesion reduced the number of NGF-R-positive cells on the lesioned side to an average of $48 \%$ of control values (Table 1), i.e., to an extent similar to the

Table 1. Effect of fimbrial transections and chronic intraventricular injections of NGF on the number of ChAT- and NGF-R-positive neurons in the medial septal nucleus and the vertical limb of the diagonal band of Broca

\begin{tabular}{lll} 
& \multicolumn{2}{l}{ Surviving neurons (\%) } \\
\cline { 2 - 3 } Group & ChAT & NGF-R \\
\hline Controls & $38.0 \pm 4.2$ & $47.6 \pm 3.0$ \\
NGF & $85.8 \pm 2.6^{a}$ & $91.9 \pm 2.2^{a}$
\end{tabular}

Animals received fimbrial transections as shown in Figure 1 and were treated during 4 weeks with NGF ( $5 \mu \mathrm{g}$ intraventricularly twice a week) or an equal amount of cytochrome $c$ (serving as control protein). Values given represent means \pm SEM derived from 8 animals in each group.

"Significantly different from corresponding controls, $p<0.001$. 

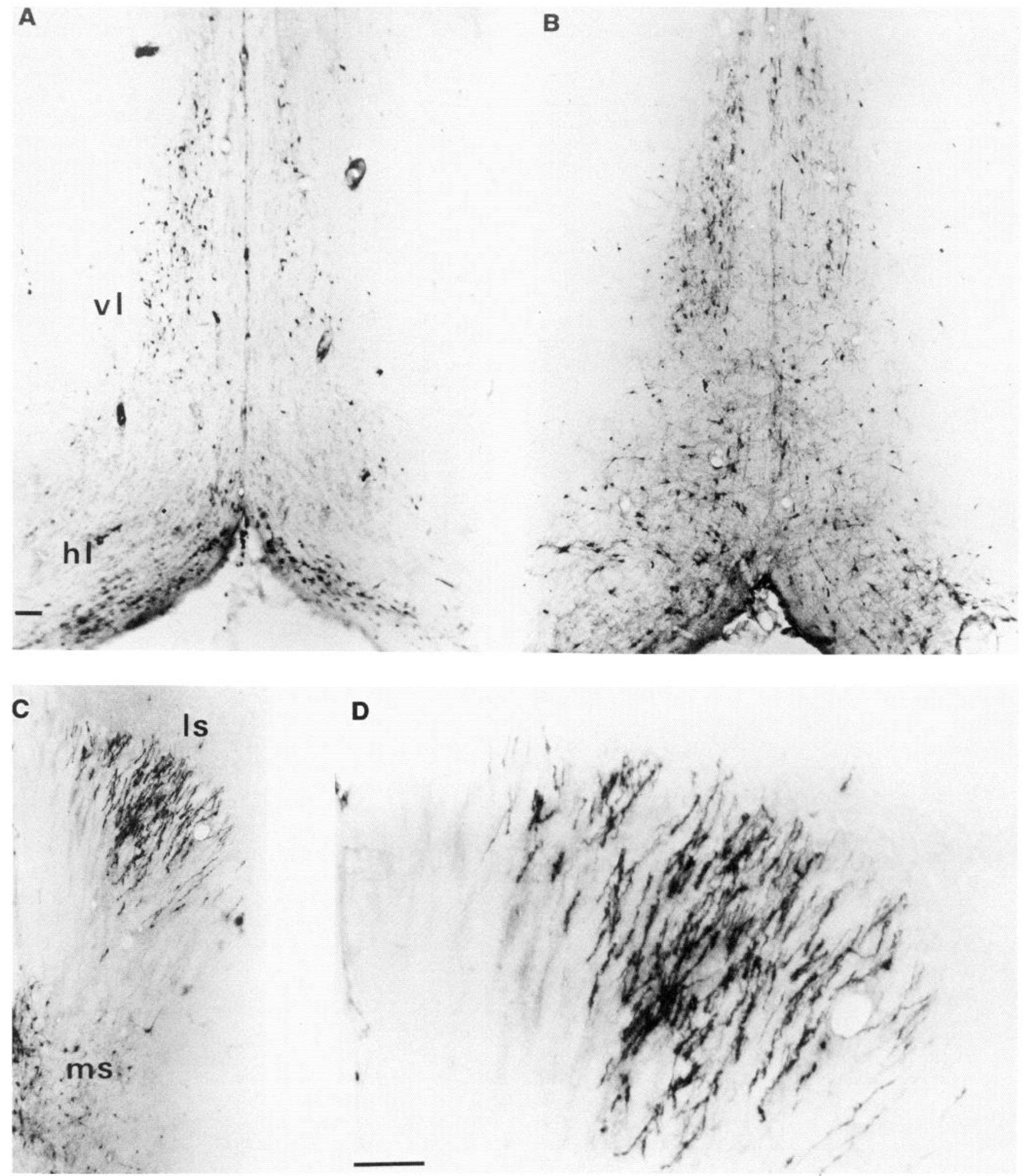

Figure 2. Effect of fimbrial transections on septal cholinergic neurons. Lesions resulted in loss of ChAT-positive cells (A) and of NGF-R-positive cells $(B)$ on lesioned (right) sides within 2 weeks after fimbrial transections. Individual rats of a group of 15 animals were killed at various time points after lesioning. The figure shows representative sections from this study. $C$ and $D$, Accumulation of NGF-R in fibers proximal to the lesion visualized $5 \mathrm{~d}$ after the lesion. Scale bars, $100 \mu \mathrm{m}$. $h l$, horizontal limb of diagonal band; $l s$, lateral septal nucleus; $m s$, medial septal nucleus; $v l$, vertical limb of the diagonal band. 
reduction in the number of ChAT-positive neurons. Between 5 and $10 \mathrm{~d}$ after the lesion, strongly stained NGF-R-immunoreactive fibers appeared in the dorsal septum of the lesioned side (Fig. 2), suggesting the accumulation of anterogradely transported NGF-R within proximal stumps of the transected axons. No similar accumulation of ChAT immunoreactivity was observed. Fimbrial transections failed to result in the appearance of NGF-R-positive cells besides those already visualized in unlesioned animals.

Identical reductions in the number of ChAT- and NGF-Rpositive cells were observed in untreated rats with unilateral fimbrial transections and animals receiving intraventricular injections of cytochrome $c$ during various intervals of time. In contrast, rats receiving repeated intraventricular injections of NGF for 4 weeks demonstrated approximately the same number of ChAT- and NGF-R-positive cells on the lesioned and control side (Fig. 3, Table 1). These findings confirm that chronic administration of NGF during 4 weeks counteracts the lesion-induced degeneration of cholinergic cells and, furthermore, suggest that NGF acts directly on NGF-R expressed by these neurons.

\section{Delayed NGF treatment}

The finding that fimbrial transections resulted in a marked reduction of the number of septal cholinergic neurons, visualized by Nissl staining, AChE, ChAT, or NGF-R histochemistry, did not fully exclude the possibility that these transections did not result in degeneration of the neurons but only in shrinkage and a down-regulation of the expression of cholinergic enzymes and NGF receptors. If this were the case, NGF treatment would stimulate the expression of transmitter-specific enzymes and NGF-R by the cholinergic neurons, bringing them to the threshold of histochemical visualization. To test for this possibility, 10 animals were lesioned but did not receive NGF treatment for 2 weeks, i.e., an interval of time sufficient for AChE, ChAT, and NGF-R staining to disappear. The rats were then treated with NGF or cytochrome $c$ for another 4 weeks. Under these conditions, no effect of the NGF treatment was observed. The number of ChAT- and NGF-R-positive neurons on the lesioned side was reduced to a similar extent in both NGF- and cytochrome c-treated animals (Fig. 4). Since delayed treatment clearly failed to result in the reappearance of cholinergic neurons on lesioned sides at cell densities seen on control sides, these results were not quantified. A reappearance of ChAT- and NGF-Rpositive cells was anticipated if the fimbrial transection had only resulted in a down-regulation of the expression of these proteins. The findings therefore suggest that the fimbrial transections indeed cause a degeneration of cholinergic neurons and that NGF, when given immediately after the lesion, promotes the survival of these cells.

\section{Requirement for chronic administration of $N G F$}

NGF was administered twice weekly during 4 weeks in all studies described so far. To test whether an initial and short NGF treatment was sufficient to prevent the degeneration of cholinergic neurons, 5 lesioned rats were given one injection of NGF the day of lesioning but received no further NGF until the end of the 4 week period. Five lesioned rats received 2 injections of NGF (on the day of lesioning and $3 \mathrm{~d}$ later) during the first week after lesioning but received no further NGF until the end of the 4 week period. Cholinergic neurons were then visualized using $\mathrm{AChE}$ histochemistry. AChE was previously shown to be a reliable marker for cholinergic neurons in the septal area (Eck- enstein and Sovroniew, 1983; Levey et al., 1983). Because of the more reliable quantification of the total number of stained cells, AChE histochemistry, rather than ChAT immunohistochemistry, was used in this study. Similar reductions in the number of AChE-positive neurons in the septal area were found in rats receiving 1 or 2 injections of $N G F$ and in rats receiving cytochrome $\mathrm{c}$ (Fig. 5). In lesioned control animals treated with cytochrome c, $53 \%$ of the AChE-positive cells remained on the lesioned sides. In animals receiving only $2 \mathrm{NGF}$ injections, the number of neurons on lesioned sides was $59 \%$ of that counted on control sides (Table 2). In contrast, and in agreement with earlier findings (Hefti, 1986), there was only a small, statistically insignificant reduction in the number of $\mathrm{AChE}$-positive neurons on the lesioned sides of rats receiving biweekly administration of NGF during the entire 4 week period. These findings indicate that short-term NGF treatment was insufficient to rescue the cholinergic neurons.

To establish whether the 4 week treatment was sufficient to rescue the cholinergic neurons permanently, 10 lesioned rats underwent an 8 week trial: NGF for 4 weeks followed by another 4 weeks without treatment. In this group, AChE histochemistry showed a loss of cholinergic cell bodies on the lesioned side similar to that seen in lesioned animals treated with cytochrome c (Fig. 5). The number of AChE-positive ncurons on lcsioned sides was $57 \%$ of that counted on control sides (Table 2). This finding suggests that NGF treatment during 4 weeks was not sufficient to ensure permanent survival of lesioned cholinergic neurons.

\section{Specificity for cholinergic neurons}

Besides the cholinergic septohippocampal neurons, the medial septal nucleus and the diagonal band of Broca contain GABAergic neurons, which may contribute to the noncholinergic septohippocampal projection (Amaral and Kurz, 1985; Wainer et al., 1985; Brashear et al., 1986; Onteniente et al., 1986). Fimbrial transections reduced the number of GAD-positive cells in the medial septal nucleus, providing evidence for the existence of a GABAergic septohippocampal projection (Fig. 6). To test for the possibility that intraventricular injections of NGF prevent the disappearance of GABAergic neurons in a similar way as that of cholinergic neurons, rats were treated with either NGF or cytochrome $c$ for 4 weeks and were taken for GAD immunohistochemistry. A special perfusion solution containing zinc dichromate at low $\mathrm{pH}$ was used for fixation. This procedure was earlier shown to result in visualization of GAD-positive cell bodies in the septal area without the use of colchicine (Mugnaini and Oertel, 1985). In animals treated with NGF or with cytochrome $c$, a marked reduction in the number of GADpositive neurons on the lesioned side was observed (Fig. 6), suggesting that the effect of NGF was specific for cholinergic septohippocampal neurons and that GABAergic neurons were not affected by the NGF treatment.

\section{Discussion}

The findings of the present study indicate that intraventricular injections of NGF prevent the lesion-induced degeneration of forebrain cholinergic neurons by directly acting on NGF-R expressed by these cells. The effect of NGF is specific for cholinergic neurons inasmuch as GABAergic neurons were not rescued, which, similar to the cholinergic neurons, disappeared after fimbrial transections. The findings furthermore establish 

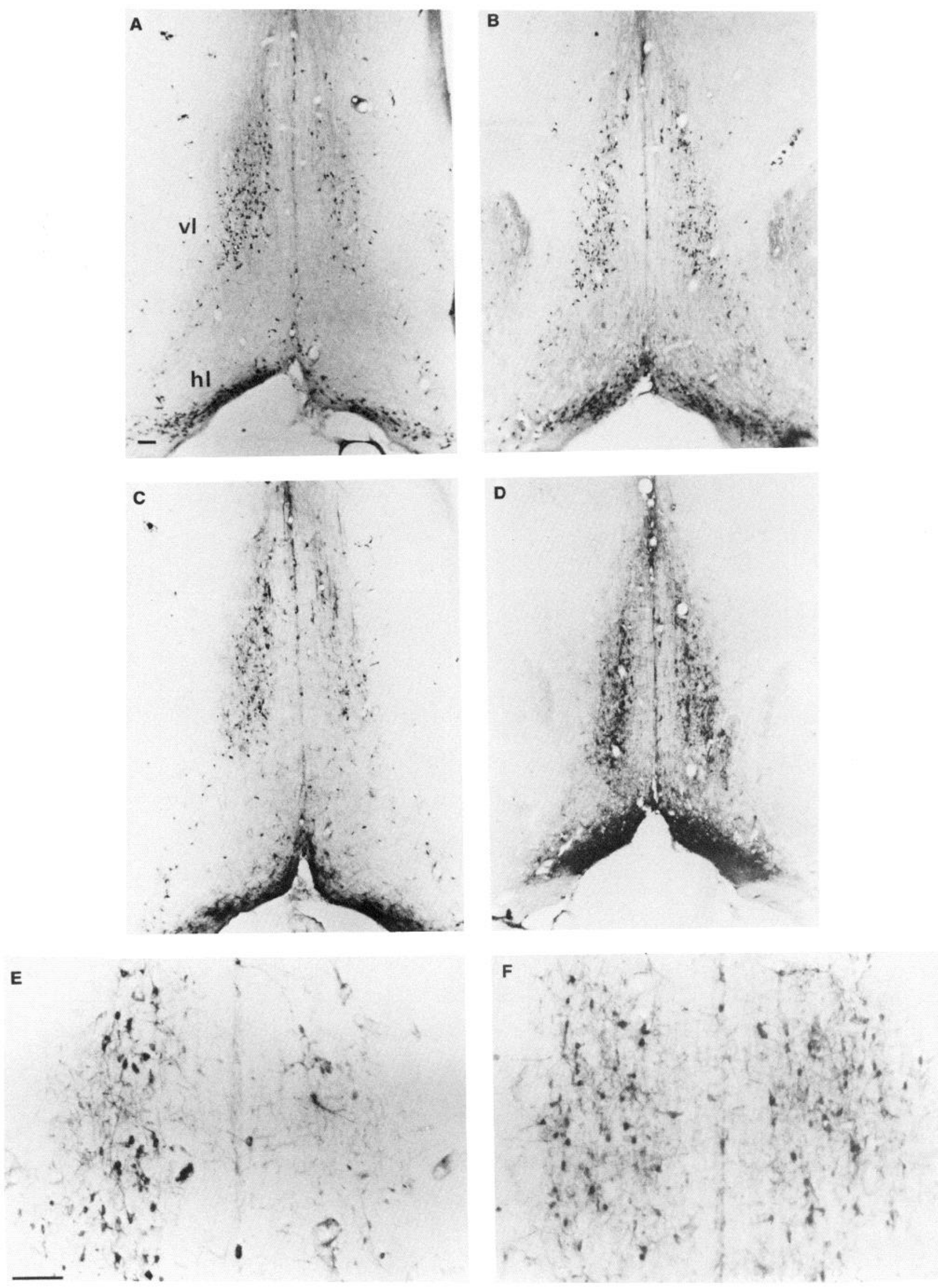

Figure 3. Chronic intraventricular administration of NGF during 4 weeks prevented the disappearance of septal cholinergic neurons visualized by ChAT immunohistochemistry $(A, B)$ and NGF-R immunohistochemistry $(C-F)$. Rats were killed $2 \mathrm{~d}$ after the last intraventricular injection. Figures on left side $(A, C, E)$ were taken from control animals treated with cytochrome c; figures on right side from NGF-treated animals. Scale bars, $100 \mu \mathrm{m}$. Eight control and $8 \mathrm{NGF}$-treated animals were used in this study. $h l$, horizontal limb of diagonal band; $v l$, vertical limb of diagonal band. 


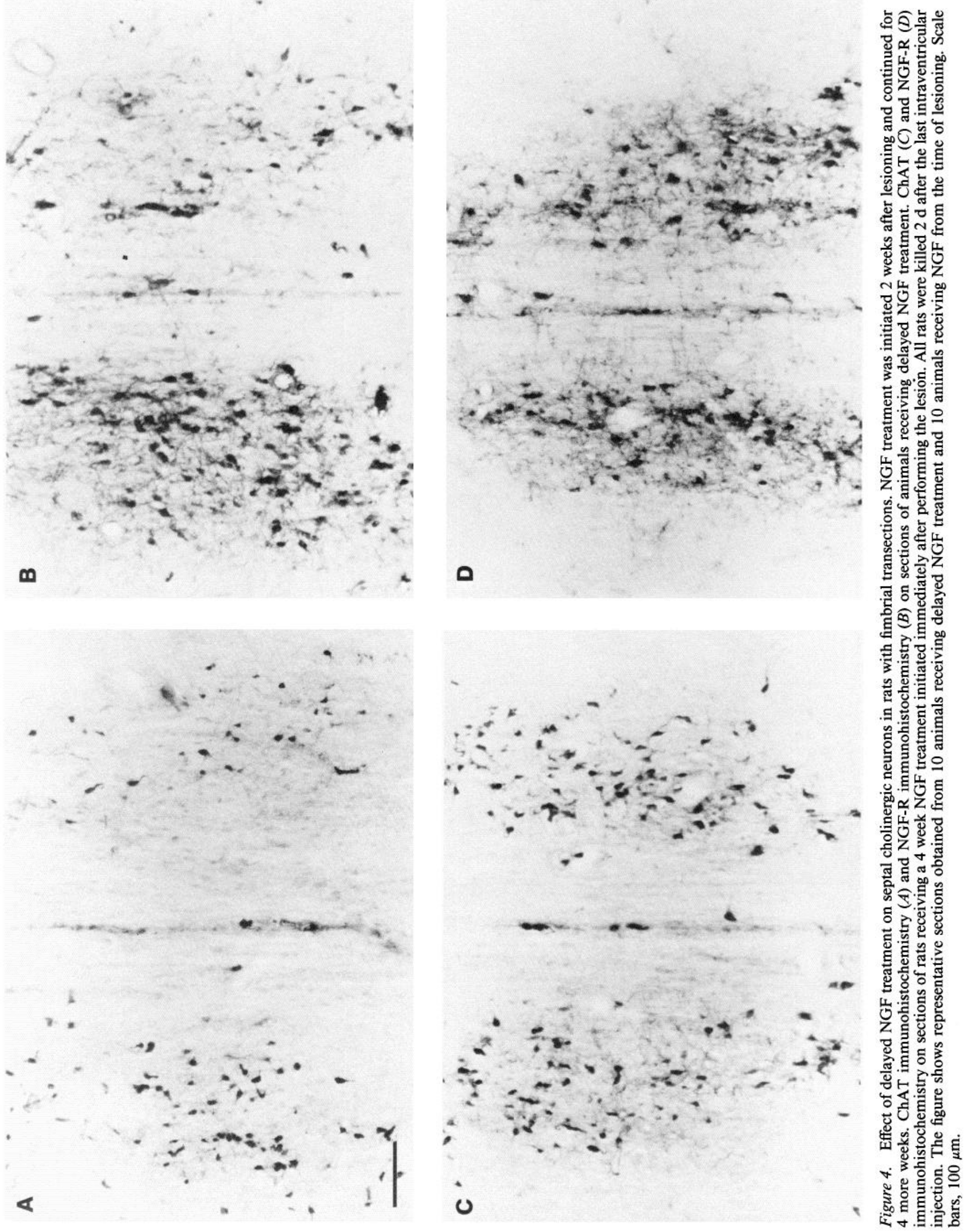



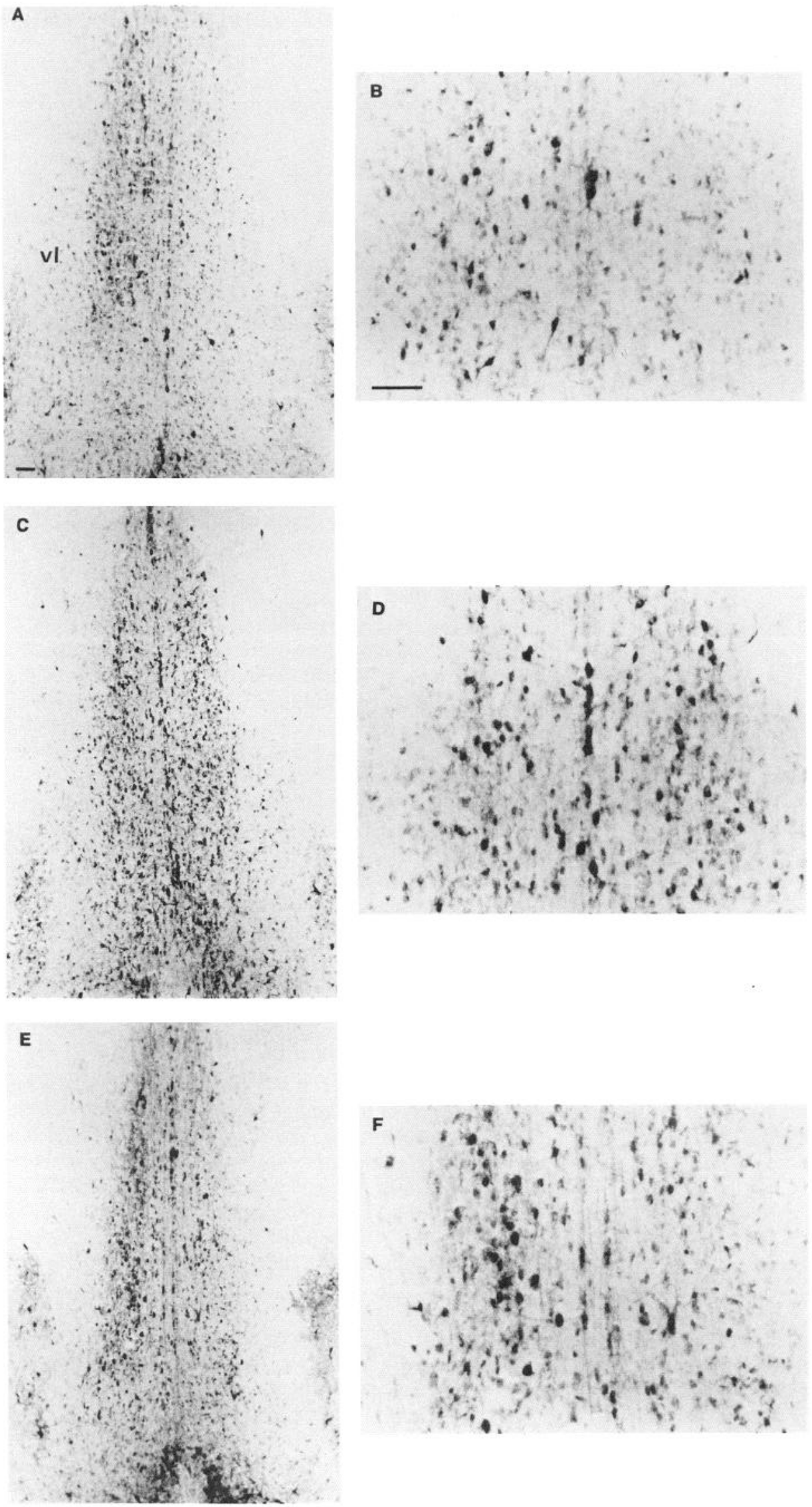
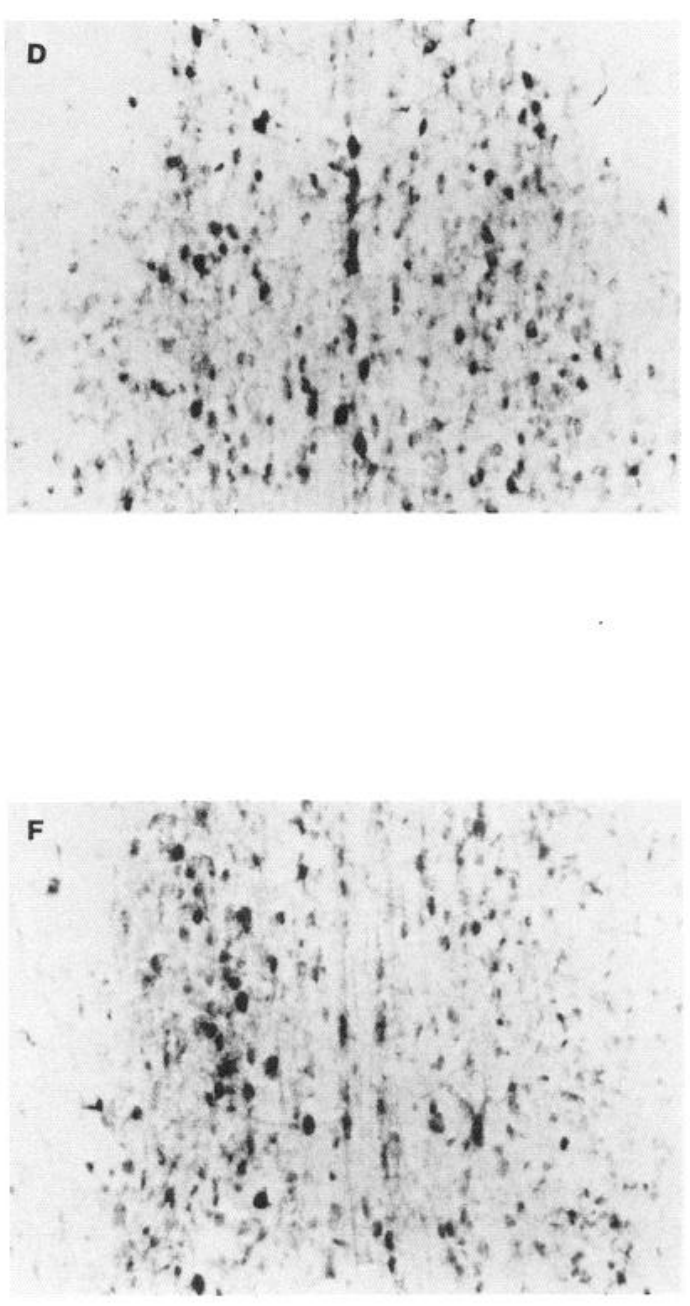

Figure 5. Requirement for chronic NGF treatment. $A$ and $B$, cholinergic neurons visualized by AChE (after DFP pretreatment) in rats receiving a single intraventricular injection of NGF at the day of lesioning and left without NGF for the rest of the 4 week period. $C$ and $D$, Cholinergic neurons in rat receiving NGF for 4 weeks and killed $2 \mathrm{~d}$ after last NGF injection. $E$ and $F$, Cholinergic neurons of rat receiving NGF during 4 weeks and killed after another 4 weeks without NGF. Scale bars, 100 $\mu \mathrm{m}$. Ten animals were used per experimental group. $v l$, vertical limb of diagonal band. 
Table 2. Requirement for chronic administration of NGF to ascertain survival of cholinergic neurons in medial septal nucleus and vertical limb of the diagonal band of rats with unilateral fimbrial transections

\begin{tabular}{llll} 
& \multicolumn{3}{l}{ AChE-positive cells } \\
\cline { 2 - 4 } Group & $\begin{array}{l}\text { Unlesioned } \\
\text { side }\end{array}$ & $\begin{array}{l}\text { Lesioned } \\
\text { side }\end{array}$ & $\begin{array}{l}\text { Surviving } \\
\text { cells (\%) }\end{array}$ \\
\hline Controls (cytochrome c for 4 weeks) & $1438 \pm 136$ & $778 \pm 111^{a}$ & $53.4 \pm 4.7^{a}$ \\
2 NGF injections + 4 weeks without treatment & $1601 \pm 88$ & $961 \pm 79^{a}$ & $59.4 \pm 2.6^{a}$ \\
NGF treatment during 4 weeks & $1511 \pm 218$ & $1343 \pm 168$ & $90.9 \pm 4.7$ \\
NGF for 4 weeks + 4 weeks without treatment & $1540 \pm 148$ & $880 \pm 112^{a}$ & $57.2 \pm 5.4^{a}$
\end{tabular}

Animals received fimbrial transections as shown in Figure 1. Controls received intraventricular injections of cytochrome $c$ during 4 weeks. The second group received intraventricular injections of NGF $(5 \mu \mathrm{g})$ at the day of lesioning and $3 \mathrm{~d}$ after lesioning, followed by 4 weeks without treatment. Animals of the third group received NGF injections twice weekly during 4 weeks and were killed $2 \mathrm{~d}$ after the last injection. Those of the fourth group were treated with NGF for 4 weeks and killed after an additional 4 week period without treatment. AChE-positive cells in the medial septal nucleus and the vertical limb of the diagonal band were counted as described in Materials and Methods. Values given represent means \pm SEM derived from 5 animals in each group.

"Significantly different from cell numbers on corresponding control sides and from the cell number on lesioned sides of animals treated with NGF for 4 weeks and killed $2 \mathrm{~d}$ after last injection $(p<0.01)$.

that NGF, at least during the first month after lesioning, must be present continuously to rescue cholinergic cells.

\section{Selectivity for cholinergic neurons}

Our findings obtained with NGF-R immunohistochemistry are in agreement with those of Springer et al. (1986), who earlier reported that NGF-R molecules are expressed exclusively in the basal forebrain of adult rats and that the number and morphology of the labeled neurons correspond to that of cholinergic neurons. Similar findings were obtained when NGF receptors were visualized using iodinated NGF in receptor autoradiography (Richardson et al., 1986; Raivich and Kreutzberg, 1987). Direct evidence for the exclusive localization of NGF-R molecules in cholinergic neurons was obtained in the human brain where NGF-R and AChE were found to be located within the same cells (Hefti et al., 1986). These findings strongly suggest that NGF given intraventricularly acts directly on cholinergic cells by binding to their NGF-R. The sequence of events resulting in cell survival remains to be established.

Williams et al. (1986) applied NGF chronically to rats with complete fimbrial transection performed by aspiration of the fimbria-fornix and the supracallosal striae. They found that these lesions strongly reduced the number of cholinergic neurons as well as noncholinergic neurons in the septal area and that NGF treatment completely prevented the degeneration of cholinergic neurons and partly attenuated the disappearance of noncholinergic neurons identified by Nissl staining. These findings contrast with our earlier observations (Hefti, 1986), which suggested that NGF treatment did not result in the rescue of Nissl-stained cells not expressing cholinergic marker enzymes. Kromer (1986), who also found that NGF rescued cholinergic neurons in rats with complete fimbrial transection, did not report any effects on noncholinergic cells. In the present study, we tested for the possibility that GABAergic neurons might be affected by NGF. The medial septal nucleus and the nucleus of the diagonal band contain a comparable number of cholinergic and GABAergic neurons (Brashear et al., 1986; Onteniente et al., 1986), and, since GABAergic neurons disappear after our fimbrial transections, it is likely that these cells give rise to at least part of the noncholinergic septohippocampal projection (Amaral and Kurz, 1985; Wainer et al., 1985). The fact that NGF treatment fails to prevent the reduction of the number of septal GABAergic neurons following the lesion suggests that NGF does not generally promote the survival of any lesioned neuron. This conclusion is also supported by studies on animals with transections of the dopaminergic nigrostriatal neurons showing that NGF fails to promote the survival of severed dopaminergic cells (Salvatierra and Hefti, unpublished observations). Furthermore, observations made with NGF-R immunohistochemistry in the present study show that the number of NGF-R-positive cells in the septal area is not increased after fimbrial transection. These findings exclude the possibility that axonal transections result in the expression of NGF-R by neurons not normally synthesizing these proteins. It is possible that part of the neuronal loss observed by Williams et al. represents transsynaptic degeneration following the disappearance of cholinergic cells. Such a secondary neuronal loss would be prevented by NGF due to its direct action on cholinergic neurons. To complete removal of the fimbria by aspiration as performed by Williams et al. results in more extensive neuronal loss than our partial transection. This difference in experimental procedures might be the basis of the discrepant data.

\section{Effect of NGF on neuronal survival}

Experiments conducted so far strongly suggest that fimbrial transection results in a degeneration of cholinergic neurons of the medial septal nucleus and the vertical limb of the diagonal band of Broca and that NGF-treatment prevents this lesion-induced degeneration. However, it could be argued that the disappearance of $\mathrm{AChE}$ and ChAT staining, which were used to visualize cholincrgic neurons in the septal area, does not reflect degeneration of cholinergic neurons but only a down-regulation of ChAT and AChE synthesis. Such an argument seems plausible, because, in the PNS, axonal transection does not result in degeneration of neurons but rather leads to the characteristic chromatolytic response of the cell body and axonal regeneration. In cholinergic motoneurons and autonomic ganglion cells chromatolysis is associated with reduced expression of AChE (for review, see Lieberman, 1971). However; results obtained with Nissl staining in rats with fimbrial transections clearly indicate a loss of large cell bodies in medial septal nucleus and diagonal band of Broca (Daitz and Powell, 1954; Gage et al., 1986; Hefti, 1986; Williams et al., 1986) and very strongly suggest that septal cholinergic neurons indeed degenerate after fimbrial transec- 
tions. However, the findings do not completely rule out the possibility that fimbrial transections did result in shrinkage associated with a complete loss of ChAT and AChE expression. Shrinkage of cholinergic neurons located in nucleus basalis has been reported to occur after cortical damage in several species (Pearson et al., 1983a, b; Sofroniew et al., 1983). However, even though smaller in size, these neurons still expressed ChAT and AChE could be visualized using histological techniques for both these markers. Furthermore, if fimbrial transection results in shrinkage rather than loss of cholinergic neurons, it would be anticipated that these neurons are stimulated by delayed administration of NGF. Our finding that delayed NGF treatment was ineffective supports the view that cholinergic neurons degenerate after fimbrial lesions. Nevertheless, further studies, in which septohippocampal neurons are labeled by nuclear markers before fimbrial transections, are required to definitely rule out that these neurons survive after axonal transections.

\section{Requirement for chronic treatment}

In all studies reporting the effects of NGF on lesioned cholinergic neurons, NGF was given chronically for a period of at least 2 weeks (Hefti, 1986; Kromer, 1986; Williams et al., 1986). However, it is possible that the presence of NGF is only required during a short time to exert its effects on cholinergic neurons. Such a notion is suggested from findings of behavioral studies reporting that single injections of NGF at the time of lesioning can facilitate behavioral recovery of animals with lesions of various brain areas (Berger et al., 1973; Hart et al., 1978; Lewis et al., 1979; Stein and Will, 1983; Eclancher et al., 1985). However, in our study, single injections of NGF failed to rescue cholinergic neurons from degeneration induced by fimbrial lesions, making it unlikely that the behavioral changes reflect actions of NGF on cholinergic neurons. Our findings do not completely exclude effects of NGF on other cells. However, at least some of the behavioral effects might be due to the renin contamination of mouse salivary gland NGF (Avrith et al., 1980; Sabel et al., 1983). Renin-free NGF was used in the one behavioral study in which NGF was given to neonatal animals (Eclancher et al., 1985).

In a previous behavioral and biochemical study (Will and Hefti, 1985), NGF was given intraventricularly to lesioned animals for 4 weeks. The animals were then left without treatment for another 6 weeks. Facilatory effects on the behavioral recovery were observed when the animals were tested immediately after termination of the NGF treatment. No behavioral differences between NGF-treated and control animals were apparent at the end of the 6 week period without NGF. However, ChAT activity in the septal area was elevated in NGF-treated animals at this time. Based on this latter finding, it was hypothesized that administration of NGF during 4 weeks results in permanent survival of septal cholinergic ncurons. The present study failed to confirm this hypothesis, since cholinergic neurons were found to be degenerated in animals treated for 4 weeks and then left without NGF for another 4 weeks. The discrepancy between the earlier biochemical findings and the anatomical findings of the present study warrant further investigation. Possibly, NGF treatment results in a permanent elevation of ChAT synthesis by surviving cholinergic neurons.

\section{Physiological role of NGF in the adult brain}

The fact that NGF is synthesized by target tissues of forebrain cholinergic neurons (Korsching et al., 1985; Goedert et al., 1986;
Shelton and Reichardt, 1986; Whittemore et al., 1986) and the selective localization of NGF-R on cholinergic neurons (Hefti et al., 1986; Richardson et al., 1986; Hefti and Mash, 1988; Raivich and Kreutzberg, 1987; Springer et al., 1987) strongly suggest that NGF is involved in the function of these neurons in the adult brain. However, such a physiological role has not been clearly established since its unequivocal demonstration would require "removal" of NGF from the brain. It seems unlikely that endogenous NGF can be neutralized by injections of antibodies to NGF, since they are not able to penetrate surrounding tissue from the site of injection. This limited ability for penetration is illustrated by the fact that anti-NGF antibodies injected into the hippocampus inhibit the ingrowth of sympathetic fibers at the site of injection only (Springer and Loy, 1985). Compounds selectively blocking the synthesis of NGF or its effect at NGF receptors are unavailable. Nevertheless, while clearly demonstrating "pharmacological" actions of exogenously administered NGF, the findings of the present study are compatible with the view of a role of endogenous NGF in maintenance of the forebrain cholinergic neurons. Adult cholinergic neurons might depend on the continuous supply of NGF provided by cells in their target areas. By depriving them of NGF, axonal transections would then result in retrograde degeneration of the cholinergic cells, and this degeneration would be counteracted by exogenous NGF. Based on this concept it can be hypothesized that cholinergic neurons which are able to reestablish contact with their target tissue during the time of the NGF treatment become independent of the exogenous source. Our recent findings (C. N. Montero and F. Hefti, unpublished observations) support this hypothesis. NGF treatment during 6 months was found to produce significant regrowth of cholinergic fibers into the hippocampus of animals with partial fimbrial transections, and termination of NGF treatment after 6 months did not result in degeneration of septal cholinergic neurons.

The amount of NGF given to lesioned rats in this or in our earlier studies (5-10 $\mu \mathrm{g} /$ intraventricular injection; Hefti et al., 1985; Hefti, 1986) represents a maximal amount that can be considered "pharmacological." This amount was originally determined from the maximal permissible viscosity of the solution used for injections through small cannulas. A maximal amount was chosen because distribution characteristics of injected NGF and its final concentration in the septal or hippocampal area were not known and could not be easily determined. We chose to establish dose-response relationships in culture systems, in which the concentration of NGF was easily controlled. NGF was found to affect forebrain cholinergic neurons in culture at concentrations similar to the reported affinity of NGF receptors (Hefti et al., 1985; Hartikka and Hefti, 1988). These findings suggest that NGF affects forebrain cholinergic neurons in vivo at concentrations similar to those mediating the well-known actions on peripheral sympathetic and sensory neurons.

Transection of the sciatic nerve and its NGF responsive sympathetic and sensory neurons results in a robust and prolonged elevation of the expression of NGF and NGF-R in the distal part of the transected nerve (Taniuchi et al., 1986a; Heumann et al., 1987) suggesting an involvement of NGF in peripheral neuronal regeneration. In contrast, there is no evidence for similar events after transection of the central septohippocampal pathway. Levels of NGF and its mRNA were measured in the denervated hippocampus, which contains both target tissue of septal cholinergic cells and the fimbria, i.e., the tissue containing cholinergic axons and which is comparable to a peripheral nerve. 


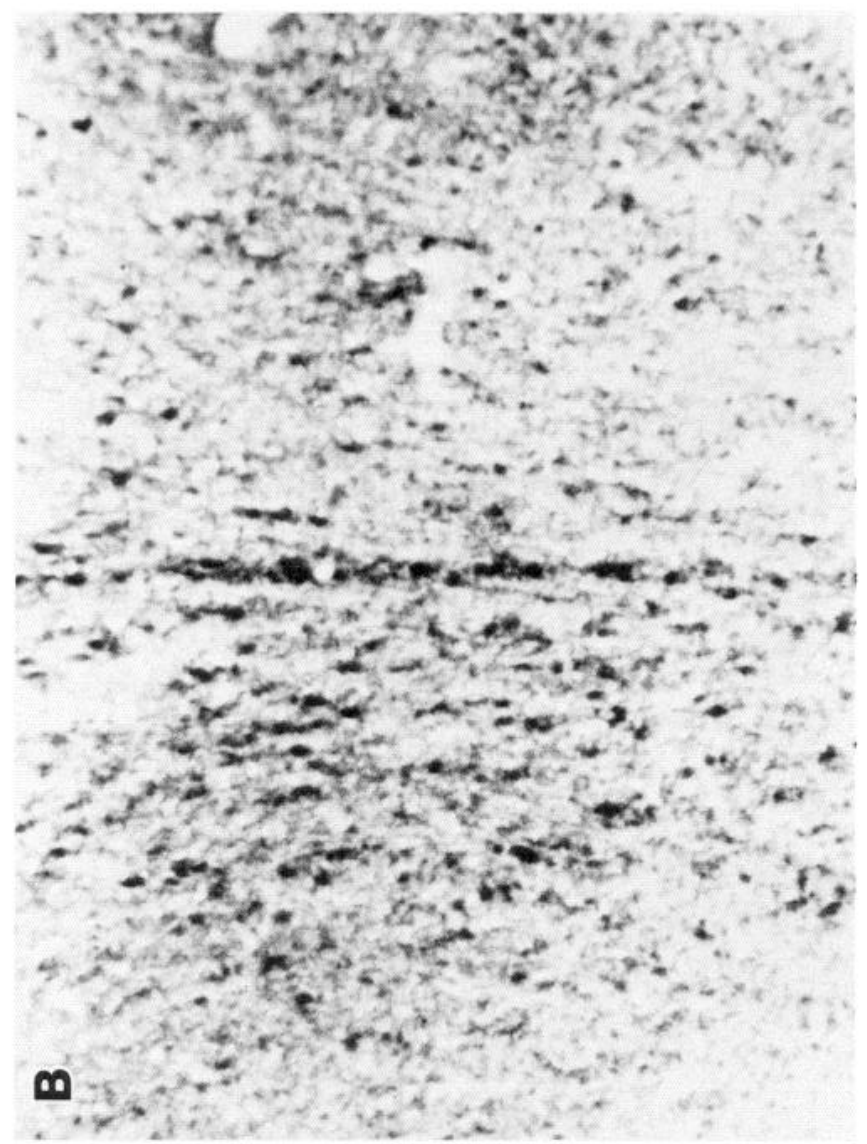

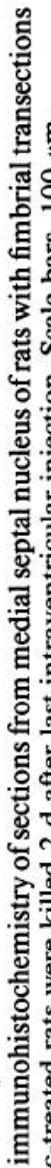

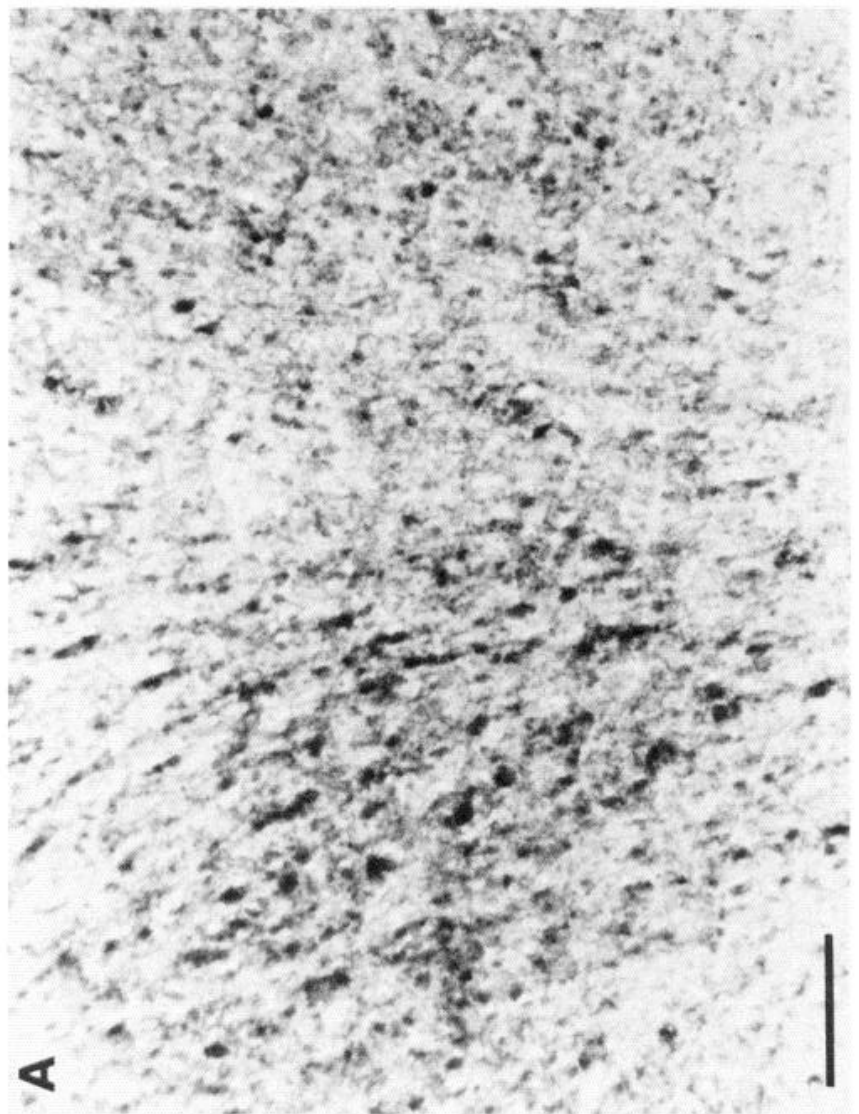


Fimbrial transection transitorily elevated hippocampal NGF levels by approximately $50 \%$ but failed to elevate mRNA ${ }^{\mathrm{NGF}}$ levels (Korsching et al., 1986). These findings contrast with those obtained on the sciatic nerve whose transection results in several-fold increases in both parameters (Heumann et al., 1987). Furthermore, transection of the sciatic nerve results in synthesis of NGF-R in segments distal to the lesion (Heumann et al., 1987). Using immunohistochemical methods these receptors were visualized in Schwann cells (Taniuchi et al., 1986b; Heumann et al., 1987). In contrast, after fimbrial transections, NGF$\mathrm{R}$ were found to appear during the first day after lesioning within neuronal fibers distal to the lesion and probably represent retrogradely transported receptors accumulating within severed cholinergic axons (Johnson et al., 1987). In confirmation of these results, we failed to find NGF-R-positive structures in the hippocampus 2 or more days after fimbrial transections in the present study. These pronounced differences between events occurring after transection of a peripheral nerve and a central pathway suggest that the lack of synthesis of neurotrophic factors and their receptors by non-neuronal cells in the central pathways might be responsible for the poor regeneration typical of central axons.

In the adult brain, NGF seems to affect only a very limited number of neuronal populations. Evidence for an involvement of NGF in the function of basal forebrain cholinergic neurons has been discussed above. It is still unclear whether NGF also affects striatal cholinergic interneurons. While there is ample evidence that these neurons respond to NGF during early development (Martinez et al., 1985; Mobley et al., 1985; Hefti et al., unpublished observations), the situation is less clear in the adult brain. Levels of NGF and $\mathrm{mRNA}^{\mathrm{NGF}}$ in the adult striatum are very low compared with hippocampal and cortical levels (Korsching et al., 1985; Shelton and Reichardt, 1986; Whittemore et al., 1986). Raivich and Kreutzberg (1987) and Richardson et al. (1986) reported visualization of NGF-R in the striatum by receptor autoradiography. However, immunohistochemical procedures using 2 different antibodies failed to visualize NGF-R in both rat and human striatum (Hefti et al., 1986; Hefti and Mash, 1987; Montero and Hefti, unpublished observations). Besides forebrain cholinergic neurons, small groups of brain-stem neurons were reported to express NGF-R in the adult rat brain (Richardson ct al., 1986; Raivich and Kreutzberg, 1987). These findings suggest that, in the adult brain, NGF's actions are highly selective for a small number of neuronal populations. In contrast, there is evidence that other neuronal populations might respond to NGF during early development (Large et al., 1986; Eckenstein, 1988).

The finding that a neurotrophic factor is able to rescue central neurons from lesion-induced degeneration has implications for understanding neurodegenerative diseases. NGF seems to affect cholinergic neurons not only after axonal transections as used in the present study but also after other types of lesions. Intraventricular NGF administration was reported to attenuate the reduction of ChAT activity in the cortex induced by ibotenic acid-induced lesions in the nucleus basalis (Haroutunian et al., 1986). Cholinergic neurons are involved in functions related to memory, and the forebrain cholinergic neurons have been implicated in the pathophysiology of Alzheimer's disease. The relationship between NGF, cholinergic neurons, and Alzheimer's disease was the subject of a recent review (Hefti and Weiner, 1986).

\section{References}

Amaral, D. G., and J. Kurz (1985) An analysis of the origins of the cholinergic and noncholinergic septal projections to the hippocampal formation of the rat. J. Comp. Neurol. 240: 37-59.

Auburger, G., P. Heumann, R. Hellweg, S. Korsching, and H. Thoenen (1987) Developmental changes of nerve growth factor and its mRNA in the rat hippocampus: Comparison with choline acetyltransferase. Dev. Biol. 120: 322-328.

Avrith, D. B., M. E. Lewis, and J. T. Fitzsimons (1980) Renin-like effects of NGF evaluated using renin-angiotensin antagonists. Nature 285: 248-250.

Berger, B. D., C. D. Wise, and L. Stein (1973) Nerve growth factor: Enhanced recovery of feeding after hypothalamic damage. Science 180: 506-508.

Brashear, H. R., L. Zaborszky, and L. Heimer (1986) Distribution of GABAergic and cholinergic neurons in the rat diagonal band. Neuroscience 17: 439-451.

Butcher, L. L., and N. J. Woolf (1986) Central cholinergic systems: Synopsis of anatomy and overview of physiology and pathology. In The Biological Substrates of Alzheimer's Disease, A. B. Scheiber and A. F. Wechsler, eds., pp. 73-86, Academic Press, New York.

Butcher, L. L., K. Talbot, and L. Bilezikjian (1975) Acetylcholinesterase neurons in dopamine-containing regions of the brain. J. Neural. Transm. 37: 127-138.

Chandler, C. E., L. M. Parsons, M. Hosang, and E. M. Shooter (1984) A monoclonal antibody modulates the interaction of nerve growth factor with PC12 cells. J. Biol. Chem. 259: 6882-6889.

Clark, G. (1981) Staining Procedures, Williams \& Wilkins, Baltimore.

Crutcher, K. A. (1987) Sympathetic sprouting in the central nervous system: A model for studies of axonal growth in the mature mammalian brain. Brain Res. Revs. 12: 203-223.

Crutcher, K. A., and F. Collins (1982) In vitro evidence for two distinct hippocampal growth factors: Basis of neuronal plasticity? Science 217: 67-70.

Daitz, H. M., and T. P. S. Powell (1954) Studies of the connections of the fornix system. J. Neurol. Neurosurg. Psychiatry 17: 75-82.

Eckenstein, F. (1988) Transient expression of NGF-receptor-like immunoreactivity in postnatal rat brain and spinal cord. Brain Res. 446: 149-154.

Eckenstein, F., and M. W. Sofroniew (1983) Identification of central cholinergic neurons containing both choline acetyltransferase and acetyl-cholinesterase and of central neurons containing only acetylcholinesterase. J. Neurosci. 3: 2286-2291.

Eckenstein, F., and H. Thoenen (1982) Production of specific polyand monoclonal antibodies to choline acetyltransferase: Characterization and use for identification of cholinergic neurons. EMBO J. 1: 363-368.

Eclancher, F., J. J. Ramirez, and D. G. Stein (1985) Neonatal brain damage and recovery: Intraventricular injection of NGF at time of injury alters performance of active avoidance. Dev. Brain Res. 19: 227-235.

Fibiger, H. C. (1982) The organization and some projections of cholinergic neurons of the mammalian forebrain. Brain Res. Rev. 4:327388.

Gage, F. H., K. Wictorin, W. Fischer, L. R. Williams, S. Varon, and A. Bjorklund (1986) Retrograde cell changes in medial septum and diagonal band following fimbria-fornix transection: Quantitative temporal analysis. Neuroscience 19: 241-255.

Gähwiler, B. H., A. Enz, and F. Hefti (1987) Nerve growth factor promotes development of the rat septo-hippocampal cholinergic projection in vitro. Neurosci. Lett. 75: 6-10.

Gnahn, H., F. Hefti, R. Heumann, M. Schwab, and H. Thoenen (1983) NGF-mediated increase of choline acetyltransferase (ChAT) in the neonatal forebrain; evidence for a physiological role of NGF in the brain? Dev. Brain Res. 9: 45-52.

Goedert, M., A. Fine, S. P. Hunt, and A. Ulirich (1986) Nerve growth factor mRNA in peripheral and central rat tissues and in the human central nervous system: Lesion effects in the rat brain and levels in Alzheimer's disease. Mol. Brain Res. 1: 85-92.

Haroutunian, V., P. D. Kanof, and K. L. Davis (1986) Partial reversal of lesion-induced deficits in cortical cholinergic markers by nerve growth factor. Brain Res. 386: 397-399.

Hart, T., N. Chimas, R. Y. Moore, and D. G. Stein (1978) Effects of 
nerve growth factor on behavioral recovery following caudate nucleus lesions in rats. Brain Res. Bull. 3: 245-250.

Hartikka, J., and F. Hefti (1988) Development of septal cholinergic neurons in culture: Plating density and glial cells modulate effects of NGF on survival, fiber growth, and expression of transmitter-specific enzymes. J. Neurosci. 8: 2967-2985.

Hatanaka, H., and H. Tsukui (1986) Differential effects of nerve growth factor and glioma-conditioned medium on neurons from various regions of fetal rat central nervous system. Dev. Brain Res. 30: 47-56.

Hefti, F. (1986) Nerve growth factor promotes survival of septal cholinergic neurons after fimbrial transections. J. Neurosci. 6:2155-2162.

Hefti, F., and D. C. Mash (1988) Localization of nerve growth factor receptors in the human brain. In UCLA Symposia on Molecular and Cellular Biology, New Series, Vol. 72: Molecular Biology of the Human Brain, E. G. Jones, ed., pp. 119-132, Liss, New York.

Hefti, F., and W. J. Weiner (1986) Nerve growth factor and Alzheimer's disease. Ann. Neurol. 20: 275-281.

Hefti, F., A. Dravid, and J. Hartikka (1984) Chronic intraventricular injections of nerve growth factor elevate hippocampal choline acetyltransferase activity in adult rats with partial septo-hippocampal lesions. Brain Res. 293: 305-309.

Hefti, F., J. Hartikka, F. Eckenstein, H. Gnahn, R. Heumann, and M. Schwab (1985) Nerve growth factor (NGF) increases choline acetyltransferase but not survival or fiber growth of cultured septal cholinergic neurons. Neuroscience 14: 55-68.

Hefti, F., J. Hartikka, A. Salvatierra, W. J. Weiner, and D. C. Mash (1986) Localization of nerve growth factor receptors in cholinergic neurons of the human basal forebrain. Neurosci. Lett. 69: 37-41.

Heumann, R., S. Korsching, C. Bandtlow, and H. Thoenen (1987) Changes of nerve growth factor synthesis in nonneuronal cells in response to sciatic nerve transection. J. Cell. Biol. 104: 1623-1631.

Honegger, P., and D. Lenoir (1982) Nerve growth factor (NGF) stimulation of cholinergic telencephalic neurons in aggregating cell cultures. Dev. Brain Res. 3: 229-238.

Honcgger, P., P. DuPasquier, and M. Tenot (1986) Cholinergic neurons of fetal rat telencephalon in aggregating cell culture respond to NGF as well as to protein kinase C-activating tumor promoters. Dev. Brain Res. 29: 217-223.

Johnson, E. M., M. Taniuchi, H. B. Clark, J. E. Springer, S. Koh, M. W. Tayren, and R. Loy (1987) Demonstration of the retrograde transport of nerve growth factor in the peripheral and central nervous system. J. Neurosci. 7: 923-929.

Koenig, J. F. R, and R. A. Klippel (1963) The Rat Brain. A Stereotaxic Atlas of the Forebrain and Lower Parts of the Brain Stem. Williams $\&$ Wilkins, Baltimore, MD.

Korsching, S., G. Auburger, R. Heumann, J. Scott, and H. Thoenen (1985) Levels of nerve growth factor and its mRNA in the central nervous system of the rat correlate with cholinergic innervation. EMBO J. 4: 1389-1393.

Korsching, S., R. Heumann, H. Thoenen, and F. Hefti (1986) Cholinergic denervation of the rat hippocampus by fimbrial transection leads to a transient accumulation of nerve growth factor (NGF) without change in mRNA ${ }_{N G F}$ content. Neurosci. Lett. 66: 175-180.

Kromer, L. F. (1986) Nerve growth factor treatment after brain injury prevents neuronal death. Science 235: 214-216.

Large, T. H., S. C. Bodary, D. O. Clegg, G. Wekamp, U. Otten, and L. F. Reichardt (1986) Nerve growth factor gene expression in the developing rat brain. Science 234: 352-355.

Levey, A. I., B. H. Wainer, E. J. Mufson, and M. M. Mesulam (1983) Co-localization of acetylcholinesterase and choline acetyltransferase in the rat cerebrum. Neuroscience 9: 9-22.

Lewis, M. E., R. M. Brown, M. J. Brownstein, T. Hart, and D. G. Stein (1979) Nerve growth factor: Effects of D-amphetamine-induced activity and brain monoamines. Brain Res. 176: 297-310.

Lieberman, A. R. (1971) The axon reaction: A review of the principal features of perikaryal responses to axon injury. Int. Kev. Neurobiol. 14: 49-123.

McKinney, M., J. T. Coyle, and J. C. Hedreen (1983) Topographic analysis of the innervation of the rat neocortex and hippocampus by the basal forebrain cholinergic system. J. Comp. Neurol. 217: 103121 .

Martinez, H. J., C. F. Dreyfus, G. M. Jonakait, and I. B. Black (1985) Nerve growth factor promotes cholinergic development in brain striatal cultures. Proc. Nat1. Acad. Sci. USA 83: 7777-7781.

Martinez, H. J., C. F. Dreyfus, G. M. Jonakait, and I. B. Black (1987)
Nerve growth factor selectively increases cholinergic markers but not neuropeptides in rat basal forebrain in culture. Brain Res. 412: 295301 .

Mesulam, M. M., and G. W. vanHoesen (1976) Acctylcholincstcraserich projections from the basal forebrain of the rhesus monkey to neocortex. Brain Res. 109: 152-157.

Mesulam, M. M., E. J. Mufson, B. H. Wainer, and A. I. Levey (1983a) Central cholinergic pathways in the rat: An overview based on an alternative nomenclature (Ch1-Ch6). Neuroscience 10:1185-1201.

Mesulam, M. M., E. J. Mufson, B. H. Wainer, and A. I. Levey (1983b) Cholinergic innervation of cortex by the basal forebrain: Cytochemistry and cortical connections of the septal area, diagonal band nuclei, nucleus basalis (substantia innominata), and hypothalamus in the rhesus monkey. J. Comp. Neurol. 214: 170-197.

Mobley, W. C., J. L. Rutkowski, G. I. Tennekoon, K. Buchanan, and M. V. Johnston (1985) Choline acetyltransferase activity in striatum of neonatal rats increased by nerve growth factor. Science 229: 284 286.

Mobley, W. C., J. L. Rutkowski, G. I. Tennekoon, J. Gemski, K. Buchanan, and M. V. Johnston (1986) Nerve growth factor increases choline acetyltransferase activity in developing basal forebrain neurons. Mol. Brain Res. 1: 53-62.

Mugnaini, E., and W. H. Oertel (1985) An atlas of the distribution of GABAergic neurons and terminals in the rat CNS as revealed by GAD immunohistochemistry. In Handbook of Chemical Neuroanatomy, Vol. 4: GABA and Neuropeptides in the CNS, Part I, A. Bjorklund and T. Hökfelt, eds., pp. 436-608, Elsevier, New York.

Oertel, W. H., D. E. Schmechel, E. Mugnaini, M. L. Tappaz, and I. J. Kopin (1981) Immunocytochemical localization of glutamate decarboxylase in rat cerebellum with a new antiserum. Neuroscience 6 : $2715-2735$.

Onteniente, B., H. Tago, H. Kimura, and T. Macda (1986) Distribution of gamma-aminobutyric acid-immunoreactive neurons in the septal region of the rat brain. J. Comp. Neurol. 248: 422-430.

Pearson, R. C. A., K. C. Gatter, and T. P. S. Powell (1983a) Retrograde cell degeneration in the basal nucleus of monkey and man. Brain Res. 261: 321-326.

Pearson, R. C. A., M. V. Sofroniew, A. C. Cuello, T. P. S. Powell, F. Eckenstein, M. M. Esiri, and G. K. Wilcock (1983b) Persistence of cholinergic neurons in the basal nucleus in a brain with senile dementia of the Alzheimer's type demonstrated by immunohistochemical staining for choline acetyltransferase. Brain Res. 289: 375-379.

Raivich, G., and G. W. Kreutzberg (1987) The localization and distribution of high affinity $\beta$-nerve growth factor binding sites in the central nervous system of the adult rat. A light microscopic autoradiographic study using [ $\left.{ }^{125} \mathrm{I}\right]$-nerve growth factor. Neuroscience 20 : 23-36.

Richardson, P. M., V. M. K. Verge Issa, and R. J. Riopelle (1986) Distribution of neuronal receptors for nerve growth factor in the rat. J. Neurosci. 6: 2312-2321.

Sabel, B. A., G. B. Kardon, and D. G. Stein (1983) Behavioral effects of intracerebral injections of renin and captopril in intact and braindamaged rats. Brain Res. Bull. 11: 637-642.

Saper, C. B., and T. C. Chelimsky (1984) A cytoarchtectonic and histochemical study of nucleus basalis and associated cell groups in the normal human brain. Neuroscience 13: 1023-1037.

Schwab, M., U. Otten, Y. Agid, and H. Thoenen (1979) Nerve growth factor (NGF) in the rat CNS: Absence of specific retrograde axonal transport and tyrosine hydroxylase induction in locus coeruleus and substantia nigra. Brain Res. 168: 473-483.

Seiler, M., and M. E. Schwab (1984) Specific retrograde transport of nerve growth factor (NGF) from neocortex to nucleus basalis in the rat. Brain Res. 300: 33-36.

Shelton, D. L., and L. F. Reichardt (1986) Studies on the expression of the $\beta$ nerve growth factor (NGF) gene in the central nervous system: Level and regional distribution of NGF mRNA suggest that NGF functions as a trophic factor for several distinct populations of neurons. Proc. Natl. Acad. Sci. USA 83: 2714-2718.

Sofroniew, M. V., R. C. A. Pearson, F. Eckenstein, A. C. Cuello, and T. P. S. Powell (1983) Retrograde changes in cholinergic neurons in the basal forebrain of the rat following cortical damage. Brain Res. 289: 370-374.

Springer, J. E., and R. Loy (1985) Intrahippocampal injections of antiserum to nerve growth factor inhibit sympathohippocampal sprouting. Brain Res. Bull. 15: 629-634. 
Springer, J. E., S. Koh, M. W. Tayrien, and R. Loy (1987) Basal forebrain magnocellular neurons stain for nerve growth factor receptor: Correlation with cholinergic cell bodies and effects of axotomy. J. Neurosci. Res. 17: 111-118.

Stein, D. G., and B. E. Will (1983) Nerve growth factor produces a temporal facilitation of recovery from entorhinal cortex lesions. Brain Res. 261: 127-131.

Suda, K., Y. A. Barde, and H. Thoenen (1978) Nerve growth factor in mouse and rat serum: Correlation between bioassay and radioimmunoassay determinations. Proc. Natl. Acad. Sci. USA 75: 40424046.

Taniuchi, M., H. B. Clark, and E. M. Johnson (1986a) Induction of nerve growth factor receptor in Schwann cells after axotomy. Proc. Natl. Acad. Sci. USA 83: 4094-4098.

Taniuchi, M., J. B. Schweitzer, and E. M. Johnson (1986b) Nerve growth factor receptor molecules in rat brain. Proc. Natl. Acad. Sci. USA 83: 1950-1954.

Wainer, B. H., A. I. Levey, E. F. Mufson, and M. M. Mesulam (1984) Cholinergic systems in mammalian brain identified with antibodies against choline acetyltransferase. Neurosci. Int. 6: 163-182.

Wainer, B. H., A. I. Levey, D. B. Rye, M. M. Mesulam, and E. J. Mufson (1985) Cholinergic and non-cholinergic septohippocampal pathways. Neurosci. Lett. 54: 45-52.

Whittemore, S. R. T. Ebendal, L. Larkfors, L. Olson, A. Seiger, I. Stromberg, and H. Persson (1986) Developmental and regional expression of $\beta$ nerve growth factor mRNA and protein in the rat central nervous system. Proc. Natl. Acad. Sci. USA 83: 817-821.

Whittemore, S. R., L. Larkfors, T. Ebendal, V. R. Holets, A. Ericsson, and $H$. Persson (1987) Increased $\beta$ nerve growth factor mRNA and protein levels in neonatal rat hippocampus following specific cholincrgic lesions. J. Neurosci. 7: 244-251.

Will, B., and F. Hefti (1985) Behavioral and neurochemical effects of chronic intraventricular injections of nerve growth factor in adult rats with fimbria lesions. Behav. Brain Res. 17: 17-24.

Williams, L. R., S. Varon, G. M. Peterson, K. Wictorin, W. Fischer, A. Bjorklund, and F. H. Gage (1986) Continuous infusion of nerve growth factor prevents basal forebrain neuronal death after fimbria fornix transection. Proc. Natl. Acad. Sci. USA 83: 9231-9235. 